\title{
Effects of antioxidants on xenobiotics-induced nephrotoxicity
}

\author{
Abbas Mohammadi ${ }^{1}$, Massumeh Ahmadizadeh ${ }^{1,2^{*}}$ \\ ${ }^{1}$ Department of Occupational Health Engineering, School of Health, Jundishapur University of Medical Sciences, Ahvaz, Iran \\ ${ }^{2}$ Physiology Research Center, Ahvaz Jundishapur University of Medical Sciences, Ahvaz, Iran
}

\section{A R T I C LE IN F O}

\section{Article Type:}

Epidemiology and Prevention

\section{Article History:}

Received: 23 October 2017

Accepted: 9 December 2017

Published online: 8 January 2018

\section{Keywords:}

Antioxidant

Oxidative stress

Kidney

Nephrotoxicity

\begin{abstract}
Implication for health policy/practice/research/medical education:
Kidney is a primary organ for excretion of endogenous and exogenous chemicals. Therefore, all toxic chemicals which are eliminated via urine pass through this organ. It also contains xenobiotics metabolizing enzymes, capable of metabolizing toxic xenobiotics. Increasing evidence supports the view that generation of oxidative stress in situ at least in part is responsible for renal failure. In animal models administration of various antioxidants protected kidney against environmental toxic chemicals. However, further studies are needed for the clinical benefit of antioxidants intervention in renal diseases.

Please cite this paper as: Mohammadi A, Ahmadizadeh M. Effects of antioxidants on xenobiotics-induced nephrotoxicity. J Renal Inj Prev. 2018;7(2):56-57. DOI: $10.15171 /$ jrip.2018.14.
\end{abstract}

K idney has been known as the main organ for most xenobiotics biotransformation. Therefore, chemically induced nephrotoxicity is taught to be produced by toxic intermediates generated in the liver and transported to the kidney. However, increasing evidence suggests that the kidney is also an important site of injury after chemical exposure. The mammalian kidney is known to be exposed to much higher level of xenobiotics than are other organs. It is primary organ for excretion of xenobiotics from the body. This organ is capable of biotransformation of wide variety of endogenous as well as exogenous chemicals $(1,2)$. It due to renal blood flow as estimated to be around $25 \%$ of cardiac output. Thus, the total amount of toxic chemicals distributed into this organ may be considerably very high. Therefore, according to its concentrating function, the kidneys usually exposed to much higher level of chemicals than are other organs.

The mechanism by which xenobiotic induced nephrotoxicity is not completely understood. However, the initial step in the pathway leading to renal toxicity is generally assumed to be biotransformation of xenobiotics to reactive intermediates by mainly cytochrome p450 present in the kidney tissue $(2,3)$. The presence of these enzyme systems in the human kidney and also in various animal species has been described by many investigators $(2,4)$. An important function of these enzymes is the metabolism of endogenous as well as exogenous compounds. The renal proximal tubular cells are the main target for metabolism of chemical induced nephrotoxicity (5). Biotransformation of chemical compounds does not fundamentally result in substrate detoxification. It has been shown that the resulting metabolites can be as toxic as parent chemical itself or even more toxic. Production of free radicals, generation of lipid peroxidation and reducing of antioxidants is known to be the essential mechanisms of xenobiotics induced nephrotoxicity (6-9).

It is assumed that generation of oxidative stress in the kidney plays a primary role in renal disorders. It is postulated that generation of oxidative stress occurs when the creation of reactive electrophile metabolites (oxidants) exceed in situ antioxidant capacity (10-12).

Large body of evidence supports the view that generation of toxic metabolites in the kidney, that is in part is responsible for renal failure. The mechanism by which antioxidant protect kidney against oxidative stress is known to be related to inhibition of free radical productions. Antioxidant molecules can react with free radicals to neutralize or cease the chain reaction before 
damaging the macromolecules and also they can accelerate the elimination of free radicals.

It is generally accepted that nutrition can regulate the adverse effects of environmental chemicals. In many basic studies in experimental animals, the administration of various kind of antioxidants including vitamins, therapeutic agents, natural diet prevented kidney function against chemical induced nephrotoxicity (1320). However, there are very few studies on the protective role of antioxidants in patients with renal failure has been reported. Further study in this subject is needed to improve the clinical benefit of antioxidant interventions in renal diseases.

\section{Conclusion}

The kidney is a target organ of many xenobiotics. This organ because of its concentrating function is exposed to much higher degree of xenobiotics than other organs. It contains xenobiotic metabolizing enzymes make it capable to metabolize. Therefore, biotransformation of toxic chemicals in situ in part showed its toxicity. It has been postulated that generation of local oxidative stress is responsible to induce renal damage. The reactive oxygen scavengers as well as antioxidant agents have been demonstrated to be effective in animal models for protecting kidney. Therefore, a diet containing antioxidant compounds is important to be considered in reducing the toxic effects of chemicals in the kidney.

\section{Author's contribution}

Both authors contributed equally to the study.

\section{Ethical considerations}

Ethical issues (including plagiarism, data fabrication, double publication) have been completely observed by the authors.

\section{Conflicts of interest}

The authors declare no conflict of interest.

\section{Funding/Support}

None.

\section{References}

1. Knights K M, Andrew Rowland A, Miners J O. Renal drug metabolism in humans: the potential for drug-endobiotic interactions involving cytochrome P450 (CYP) and UDPglucuronosyltransferase (UGT). Br J Clin Pharmacol. 2013; 76:587-602. doi: $10.1111 / \mathrm{bcp} .12086$

2. Lock EA, Reed CJ. Xenobiotic metabolizing enzymes of the kidney. Toxicol Pathol. 1998;26:18-25.

3. Lohr JW, Willsky GR, Acara MA. Renal drug metabolim. Pharmacol Rev.1998;50:107-41.

4. Carvalho M, Hawksworth G, Milhazes N, Borges F, Terrence J, Monks TJ, et al. Role of metabolites in MDMA (ecstasy)-induced nephrotoxicity: an in vitro study using rat and human renal proximal tubular cells. Arch Toxicol. 2002;76:581-88.

5. Irving RM, Elfarra AA. Role of reactive metabolites in the circulation in extrahepatic toxicity. Expert Opin Drug Metab Toxicol. 2012;8:1157-72. doi: $10.1517 / 17425255.2012 .695347$.

6. Ramm S, Adler M, Vaidya VS. A high-throughput screening assay to identify kidney toxic compounds. Curr Protoc Toxicol. 2016;69:9.10.1-9.10.16. doi: 10.1002/cptx.12

7. Keiko Hosohata .Role of oxidative stress in drug-induced kidney injury. Int J Mol Sci. 2016;17:1826. doi: 10.3390/ ijms17111826

8. Tylicki L, Rutkowski B, Hörl WH. Antioxidants: a possible role in kidney protection. Kidney Blood Press Res. 2003;26:303-14.

9. Ali BH, Al-Salam S, Al Suleimani Y, Al Kalbani J, Al Bahlani $\mathrm{S}$, Ashique $\mathrm{M}$, et al. Curcumin ameliorates kidney function and oxidative stress in experimental chronic kidney disease. Basic Clin Pharmacol Toxicol. 2018;122:65-73. doi: 10.1111/ bcpt.12817.

10. Singh D, Kaur R, Chander V, Chopra K. Antioxidants in the prevention of renal disease. J Med Food. 2006;9:443-50.

11. Lobo V, Patil A, Phatak A, Chandra N. Free radicals, antioxidants and functional foods: Impact on human health. Pharmacogn Rev. 2010;4:118-26.

12. Luciak M. Antioxidants in the treatment of patients with renal failure. Rocz Akad Med Bialymst. 2004;49:157-61.

13. Yesilyurt A, Aydın Erden I, Bilgiç I, Erden G, Albayrak A. The protective effect of erdosteine on radiocontrast induced nephrotoxicity in rats. Environ Toxicol. 2011;26:395-402. doi: 10.1002/tox.20691.

14. Morshedi R, Ahmadizadeh M, Ahmadi Angali K. Protective effects of zinc supplementation on renal toxicity in rats exposed to cadmium. Jundishapur J Health Sci. 2014;6:e21717. doi: 10.5812/jjhs.21717.

15. Abdel-Gayoum AA, Ahmida MHS. Changes in the serum, liver, and renal cortical lipids and electrolytes in rabbits with cisplatin-induced nephrotoxicity. Turk J Med Sci. 2017;47:1019-27. doi: 10.3906/sag-1602-136.

16. Tutanc M, Arica V, Yllmaz N, Nacar A, Zararsiz I, Basarslan F, et al. Effects of erdosteine on cyclosporin-A-induced nephrotoxicity. Hum Exp Toxicol. 2012;31:565-73. doi: 10.1177/0960327111417907.

17. Palipoch S. A Review of Oxidative Stress in Acute Kidney Injury: Protective Role of Medicinal Plants-Derived Antioxidants. Afr J Tradit Complement Altern Med. 2013;10:88-93.

18. Ahmadizadeh M, Ebrahim Abdolkany E. Afravy M. The preventive effect of vitamin $c$ on styrene-induced toxicity in rat liver and kidney. Jundishapur J Health Sci. 2015;7:e26849. doi: $10.5812 /$ jjhs.26849v2.

19. 19. Afravy M, Angali K, Khodadadi A, Ahmadizadeh M.The protective effect of buffalo's milk against toluene induced nephrotoxicity in rats. J Nephropathol. 2017;6:1749. doi:10.15171/jnp2017.30.

20. Heydari M, Ahmadizadeh M, Ahmadi Angali K. Ameliorative effect of vitamin $\mathrm{E}$ on trichloroethylene induced nephrotoxicity in rats. J Nephropathol. 2017;6:16873. doi: 10.15171/jnp.2017.29.

Copyright (c) 2018 The Author(s); Published by Nickan Research Institute. This is an open-access article distributed under the terms of the Creative Commons Attribution License (http://creativecommons.org/licenses/by/4.0), which permits unrestricted use, distribution, and reproduction in any medium, provided the original work is properly cited. 